\title{
Challenges and Expectations towards Information Literacy Skills: Voices from Teachers' Training of Scientific Writing
}

\author{
Hasan Subekti \\ Postgraduate Doctoral Student of Biology Education Program \\ Universitas Negeri Malang, Indonesia \\ Herawati Susilo, Ibrohim and Hadi Suwono \\ Universitas Negeri Malang \\ Malang, Indonesia \\ Martadi and Aris Rudi Purnomo \\ Universitas Negeri Surabaya \\ Surabaya, Indonesia
}

\begin{abstract}
This research was aiming at analyzing information literacy skills (ILS) among teachers, the challenges of mastering ILS, and the expected ILS training. The study involved 58 secondary school teachers in East Java, Indonesia. The questionnaire and the information literacy test were administered after the training to capture the data. The data were then descriptively analyzed with NVivo 12 and Minitab 16 Windows. The results have shown that more than half of all participants had scores below the standard of 70 . The other findings indicated that the teachers were good at determining types of information and understanding research terminologies. However, they were still not successfully extracting what was important in mastering ILS determined by eight other indicators. To employ ILS, teachers should deal with the challenges, such as time management, motivation, and knowledge of writing. To sum up, the teachers still need more training sessions which focus on the continuity of making scientific articles for professional development. This training can even build some foundation to improve ILS to teachers.
\end{abstract}

Keywords: Challenges, Expectations, Information literacy, Scientific articles, Teachers, Writing.

\section{Introduction}

Technology development is rapidly changing and surpassing the expectation of people living in the industrial era of 4.0. It dominantly affects how they use 
technology products to develop information processing (De Meulemeester, De Maeseneer, De Maeyer, Peleman, \& Buysse, 2019; Samani, 2017). Reading and thinking particular events are even more accessible, and in a day-to-day situation, they always provide personal judgment. To deal with that, they have to bring various skills in terms of personal and social supports, which are related to the so-called information literacy skills (ILS) (McGuinnes \& Fulton, 2019; Shorsher \& Bronstein, 2018).

ILS refers to a thorough process of understanding information (Koltay, Špiranec, \& Karvalics, 2016) by which people identify, understand, interpret, generate, communicate, and calculate various context of ILS (Ahmadi \& Yulianto, 2017; UNESCO, 2017b). Therefore, it benefits the production of problem-solving, decision making, research value (Zane \& Tucci, 2015), and development in multidisciplinary expertise (Kavšek, Peklaj, \& Žugelj, 2016; Shao \& Purpur, 2016; UNESCO, 2017b;). Other individuals see ILS involves reflective information discovery, recipiency of how information is obtained, constructed, evaluated, and used to build a piece of new knowledge or capability ethically and legally in the learning community (Corrall, 2017; Budd \& Suorsa, 2019). In other words, ILS are related to a series of intellectual aspects of writing (Bailey, Maher, \& Wilkinson, 2018; Flierl, Bonem, Maybee, \& Fundator, 2018; Subekti, Purnomo, Susilo, Ibrohim, \& Suwono, 2018a), which are routinely used to enable lifelong learning (Liou, Yu, Tsai, \& Cheng, 2015).

Indonesia has already developed and has been practicing such relevant skills (Ahmadi \& Yulianto, 2017; Ibrahim et al., 2017) to provide quality human resources (Subekti, Purnomo, Susilo, Ibrohim, \& Suwono, 2018a). One of the studies found that during the program supporting information literacy, teachers often asked their students to find the information offline and online in the library. It was useful to strengthen the capability of learning (McDougall, Readman, \& Wilkinson, 2018). In such, the curriculum mandates the schooling system to provide opportunities for students to access an open and wide variety of information. Eventually, it brings about problem-solving skills (Khan, Idrees, Asghar, \& Aziz, 2016).

The opposition, however, argue that ILS practices seem to be problematic, especially for teachers as a result of schooling systems mandating ILS in the curriculum (Cicek, Cankaya, Ucer, \& Cetin, 2017; Feng \& Ha, 2016) to support learning experience (Chiarella, Khadem, Brown, \& Wrobel, 2014). Some research findings proofed that there are various problems for teachers in their fields, including difficulty in using information technology in the learning process (Alba \& Trani, 2018; Swaramarinda, 2018; Ivanova, Frolov, \& Nikulchev, 2016; Montrieux, Vanderlinde, Schellens, \& De Marez, 2015), and in seeking information (Subekti, Purnomo, et al., 2018b). As a consequence, when the teachers are asked to write scientific articles as part of their professional works (Graham, 2018), the products tend to be low in quality (Goldsmith, Willey, and Boud, 2017) in terms of relevancy of references and productivity in the writing (Susantini, Sri, Budiono, \& Raharjo, 2015). For this, they then need some pieces of training to maximize their potentials in terms of ILS. In doing so, the teachers are required to build their awareness of information. 
Writing ubiquitous and scattered information into a reasonable and logic form is mandatory for teachers and coherent with the teacher professional development (Kemendikbud, 2016a; Kemendikbud, 2016b). It also plays a necessary contribution to ILS development by which the teachers try to make sense all information and to formulate their understanding by putting in words. However, lack of infrastructure support in schools, such as low connectivity of Wi-fi, computer shortage, and the small number of literature, tends to decrease teachers' skills in extracting information from the sources. In such a case, some teachers are supported only by the use of personal smartphone and laptops at home. Also, teachers do not have enough time to write scientific information and make them literate enough to the available information from the literature and the internet because they have to teach 40 hours a week (Hidayati, Fatkhurahman, \& Suroto, 2017). Each day contains 8 hours work; and indeed, only on Saturday, they have free time to teach. Therefore, only those who are struggling themselves and prioritizing their career development deserve information literacy in terms of writing skills as stated in the policy of the Minister of State for Administrative Reform number 84 the year 1993 (Aisyah \& Mahanani, 2017).

This article then comes up with the analysis of ILS among teachers when they access online sources and do practical writing training sessions. Then, the research questions to be asked here are (a) how are ILS of the teachers, (b) what obstacles are encountered by teachers to gain ILS through writing scientific articles, and (c) what is the type of training needed in the domain of science education, especially in Indonesia to improve ILS. Here, the ILS is considered to have a connection between online sources and writing practices. Thus, this research leads to prepare future programs in improving progress on teachers' ILS.

\section{Method}

This research is categorized as descriptive research (Chu \& Ke, 2017) or also known as survey research (Edmonds \& Kennedy, 2017; Leavy, 2017; Lune \& Berg, 2017). The survey for research techniques (Bordens \& Abbott, 2018) that enable researchers to formulate group characteristics or measure their attitudes and opinions towards problems (Alqahtani et al., 2019; Krahe, Milligan, \& Reilly, 2019) whose phenomena in the context of research are ILS, difficulties in writing scientific articles, and types of exercises expected.

The research involved 58 teachers from different senior high schools in East Java Province, Indonesia, who are under the status of a civil servant. They participated in a two-week teacher training, which focused mainly on the use of information on writing scientific articles. The activities include introducing why ILS is vital, making a final report of action research, writing scientific articles, presenting results through a poster for information exhibition, and reading vast information to strengthen the shape of their writing skills. The size of participants is by purposeful sampling relevant to design goals, target population (Edmonds \& Kennedy, 2017) and the topic (Hai-Jew, 2015) with respect to two interrelated causes; first, the participants' readiness to complete 
the questionnaire and take the ILS test; and second, the representativeness of the participants of each district/city within East Java Province.

The questionnaire and the literacy test were the instruments used in this research. The questionnaire contained information about participants' demographics including names, gender status, civil servants' ID (NIP), fields of teaching, teaching period, working institution, scientific article writing constraints, and expected training activities that are considered necessary in the field of education. The literacy test consisted of questions about various forms of choice that refer to 32 literacy abilities. The indicator components of the literacy test included (a) choosing various sources of references, (b) considering the importance of copyright issue, (c) understanding research terminologies, (d) writing scientific articles systematically, (e) analyzing information from books, (f) analyzing information on the internet, (g) exploring for information on the internet, (h) gaining skills for searching information, (i) determining types of information, and (j) prioritizing selected information (Cicek, Cankaya, Ucer, \& Cetin, 2017; Çoklar, Yaman, \& Yurdakul, 2017; Nwosu, Obiamalu, \& Udem, 2015; Shao \& Purpur, 2016; Saunders, 2018; Shreffler \& Gauder, 2018).

The form of data analysis are descriptions or text, code, and questions (Maher, Hadfield, Hutchings, \& Eyto, 2018), with the ease of the NVivo 12 program to get visualization decisions. With NVivo software, the use of "node" allows investigators to rely on qualitative data (Kim et al., 2016; Woolf \& Silver, 2018). Meanwhile, numerical analysis can be done by using software (Kim et al., 2016), namely the Minitab 16 analysis and describes the results of the data analysis decision visualization. For determining the quality of ILS, the total score compares to a standard score of 70 (Slavin, 2018), which is the total score of the ILS indicators. The results determine whether the teachers need further scientific writing training or not.

\section{Results and Discussion}

Data obtained in this research are the participants' demographic data, the description of the constraints in the writing of scientific articles, and the training that is considered necessary in developing their capabilities as teachers and testing the data of ILS. Explanation in detail on (a) the results of the participants' demographic analysis, (b) the analysis of ILS, (c) the analysis of articles writing constraints, and (d) the expected training analysis results.

\subsection{Demographic analysis of Participants}

This research focuses on educators participating in scientific writing exercises held at one of the government education and training institutions in East Java Province, Indonesia. Participants are teachers from three types schools including senior high school (SMA), vocational school (SMK), and special school (SLB) with the same level from 29 cities in East Java. The distribution pattern of those schools is in Figure 1 below. From the figure, it is only Malang, and Situbondo did not send their representative teachers to the training. 


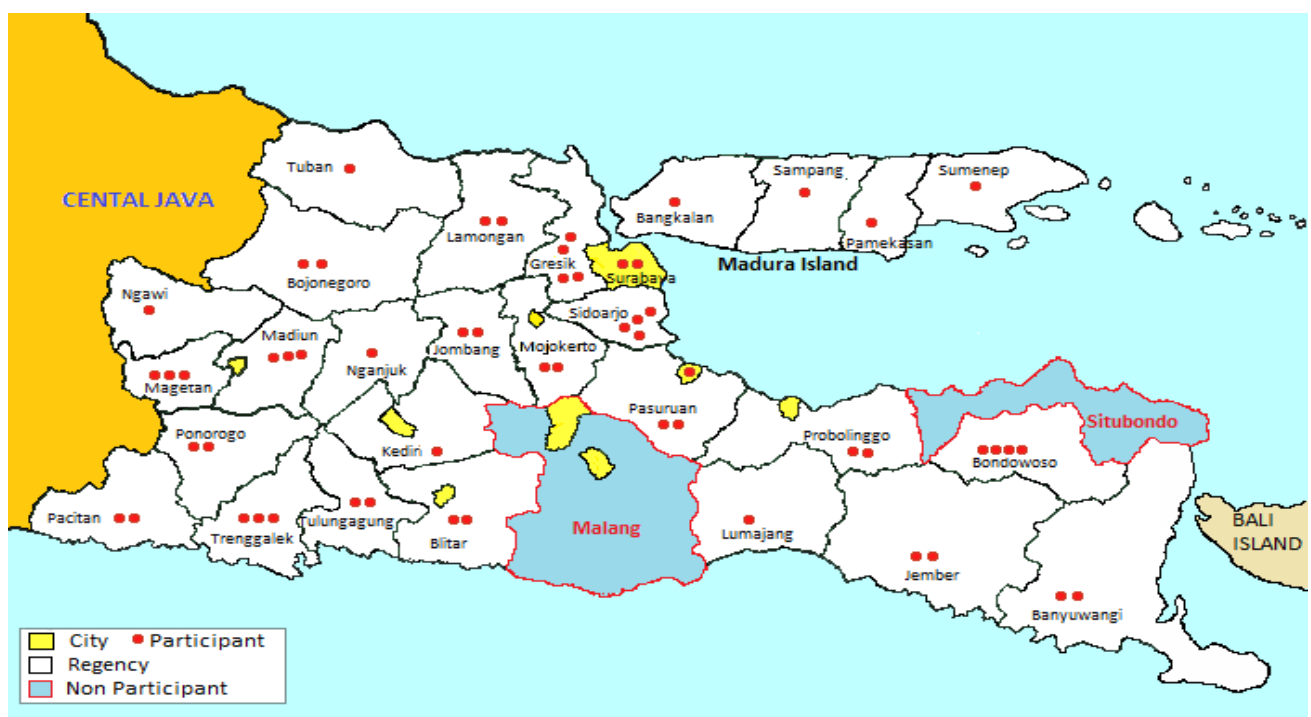

Figure 1. The distribution of schools participated in the research

The participants consisted of 23 men (39.7\%) and 35 (60.3\%) women. At the time this research was conducted, the teachers have shown 12-13 years of teaching experience on average. Moreover, some of the junior teachers had four years of teaching experience, whereas the senior teachers experienced teaching for 34 years. Among these participants, the highest number of teachers had teaching experience of 8 to 16 years. The shortest are these with more than 24 years of teaching practice. The diagram below shows the various amount of teaching experiences of the participants.

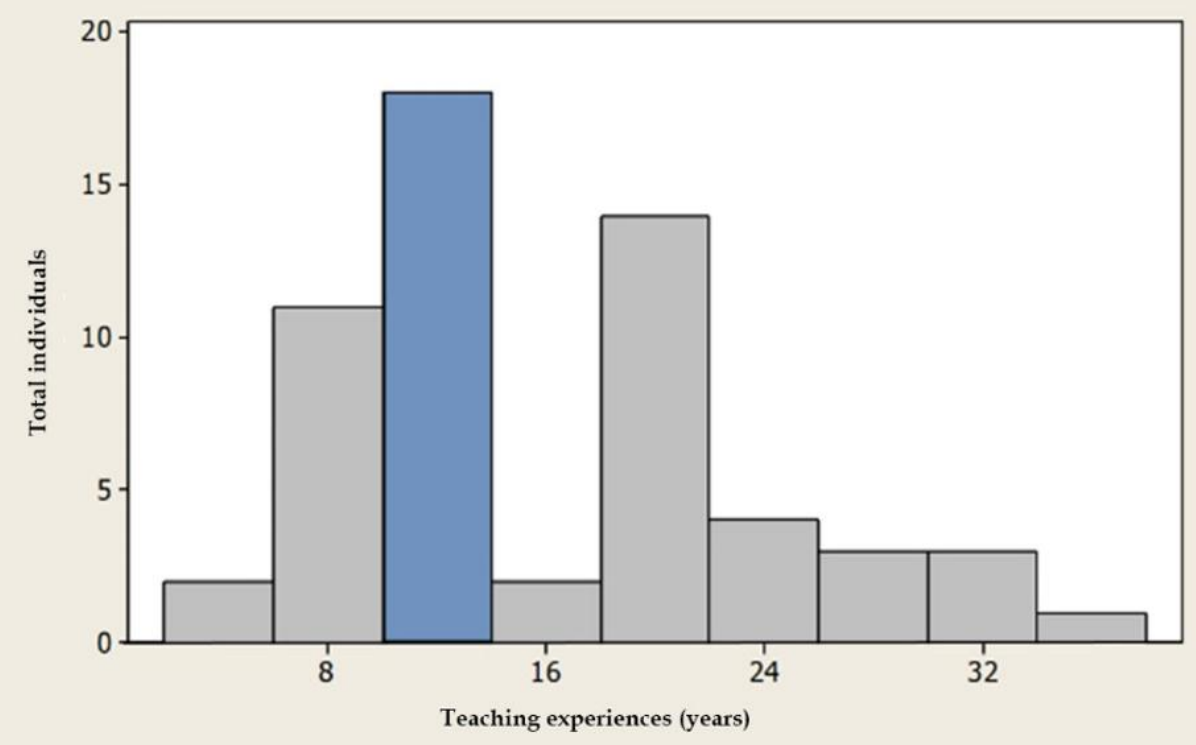

Figure 2. The diagram of teaching experience of made using Minitab 16

According to Figure 2, the participants' demography is categorized based on scientific clusters. The NVivo Map Tree in the following figure draws a picture of participants based on four scientific clusters namely (a) language, (b) natural 
sciences and mathematics, (c) social sciences, and (d) engineering. The visualization shows that the majority of participants were teachers of Indonesian language [Bahasa Indonesia]. In the field of mathematics and natural sciences, the teachers generally taught physics and chemistry, whereas in social science the teachers possessed the field of study of accounting. In engineering, automotive is still at most.

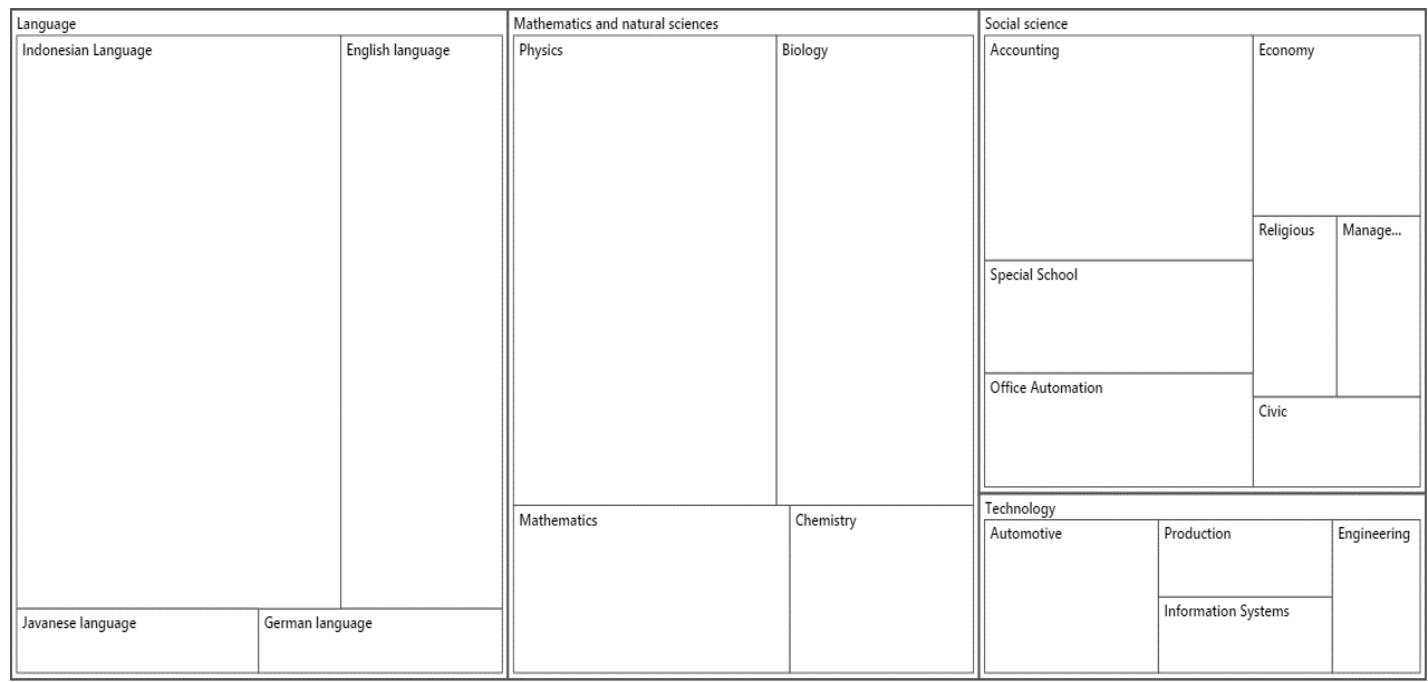

Figure 3. NVivo Tree Map on participants' demographics based on scientific clusters

\subsection{Analysis of teachers' capabilities of ILS}

ILS is an essential skill to record, evaluate, and provide appropriate analysis of information to foster informatics capabilities (Liou et al., 2015). In line with that reference definition, ILS is one of the information literacies related to the capability to recognize when information is needed, and competencies in making final decision which involve searching, analyzing, and evaluating the information itself (Liou et al., 2015; Sardon \& Tignor, 2018; Ukachi, 2015). The visualization of ILS is in Figure 4.

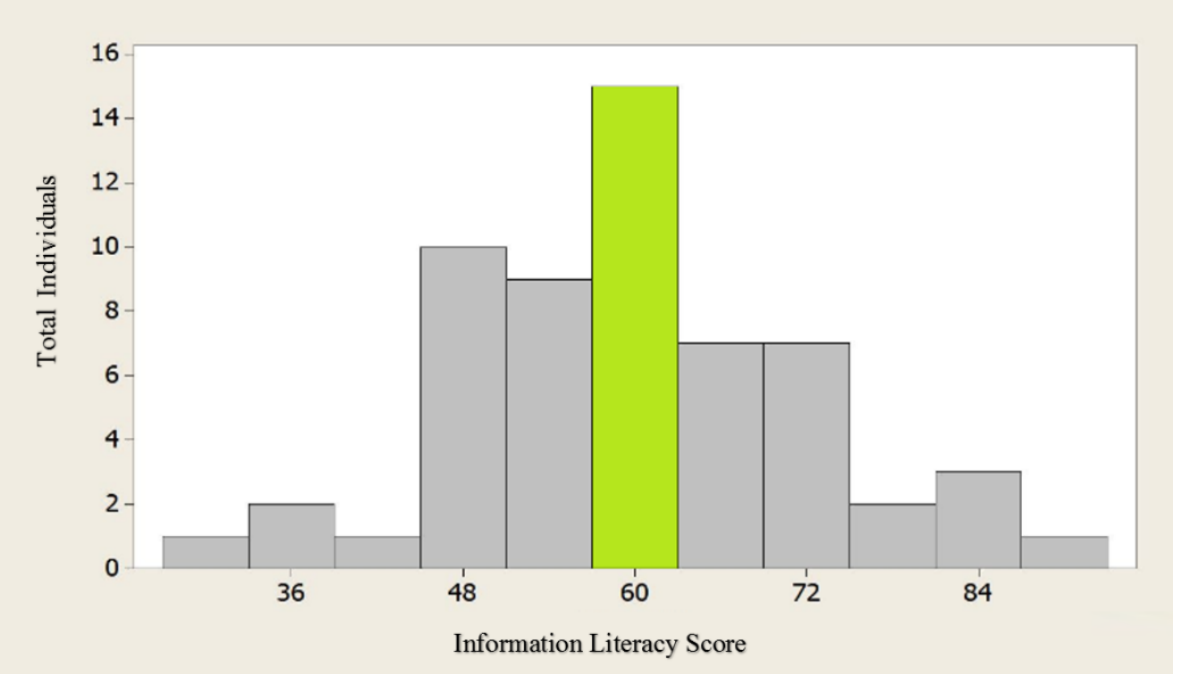

Figure 4. The ILS histogram score using Minitab 16 
Referring to the ILS histogram score in Figure 4, it shows that the highest score of ILS is more than 84, whereas the lowest score is less than 36. Most of the teachers possess a score of 60 with the total number of 15 individuals; outperforming almost half of the teachers participating in the training session. The remaining 21 teachers get the score of more than 60 . By looking at the standard score, which is at least 70, more than half of participants do not pass the score. The average is still below 70, which is 59.5. These demonstrate the alignment of the findings on the need for efforts to improve ILS for teachers.

Although the scores seen in Figure 4 indicated that only 12 teachers have higher scores than the standard score, Figure 5 below shown new data. The number of teachers who may have lower scores than the standard score varies in mastering indicators. The highest percentage is in the indicator of determining types of information. In such a case, mostly, the teachers are familiar with different kinds of information. See, e.g., Walker and Li (2016) work, they noted that by knowing types of information, such as Wikipedia, people are likely to have broader knowledge, and thus, are capable of determining the level of the reliability over the information they read. The second highest percentage understands research terminologies with $77 \%$. Teachers accommodate the knowledge to explain what research terminologies mean to them. Likely, these findings are similar to the research of prospective science teachers who also put both indicators that have a reasonably high score compared to others (Subekti et al., 2018). Shao and Purpur (2016) contended that the multiple sources of information and the way people understand it are critical to the knowledge system. Moreover, mastery in research terms will contribute to mapping how information is made, disseminated, and used in research for ILS (Subekti, Yuhanna, Susilo, Ibrohim, \& Suwono, 2018).

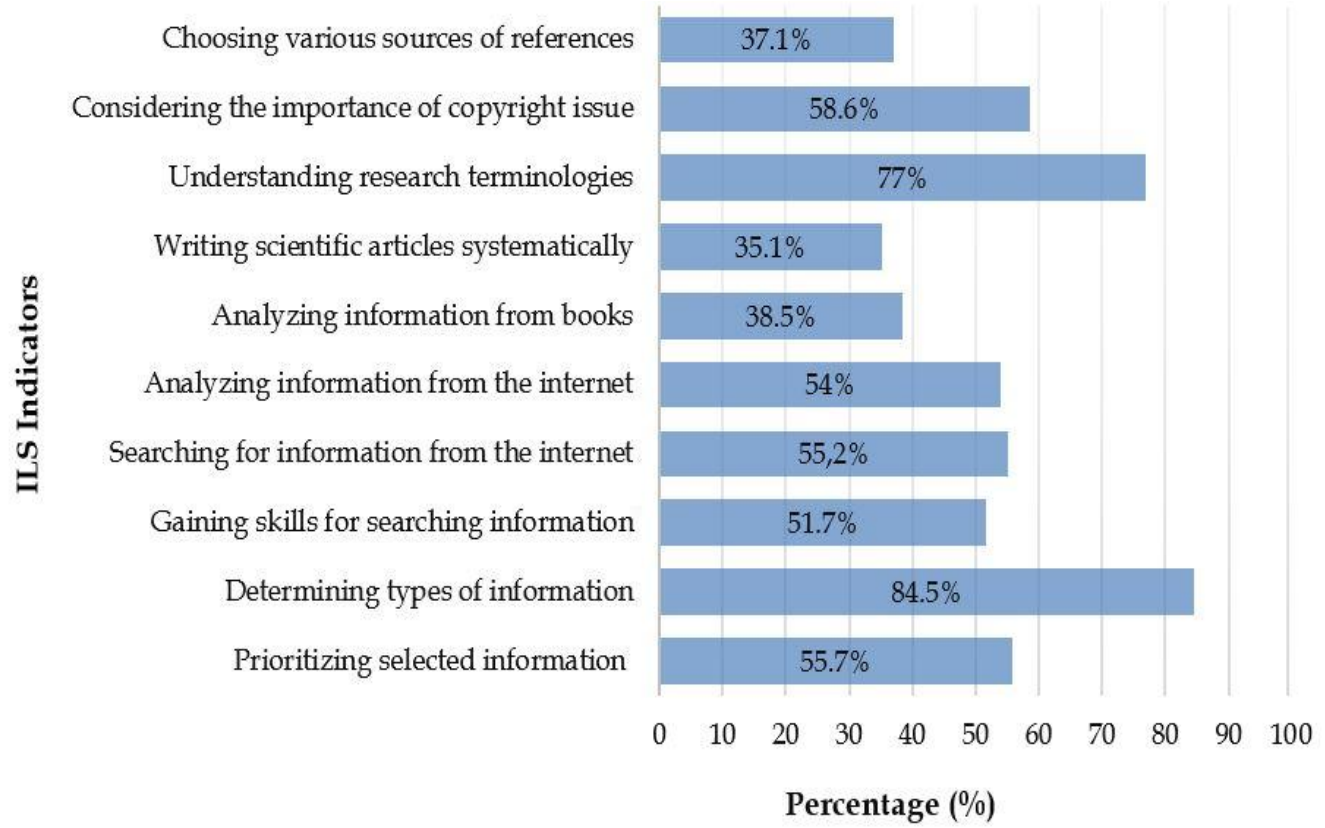

Figure 5. Summary of achievement indicator of ILS 
The majority of ILS indicators is acquired by the teachers with the percentage between $50 \%$ to $60 \%$, including copyright issue, available information on the internet, and information selection. This data, by far, proves that $50 \%$ of participants are familiar with the use of technology to search for and manage information. Çoklar, Yaman, and Yurdakul (2017) recommended three themes for these results, that is, (a) establishing level of information required, (b) accessing the required information, (c) using ethics in the usage of information.

The lowest percentage of participants' ILS mastery is using the systematics of scientific writing (35.1\%). The discovery of this data is one of the factors that drive high plagiarism and incompatibility between citations and references in scientific papers. These results are consistent with the research involving preservice science teachers who produce correct answers of $31.3 \%$ on the question about plagiarism indicating that they are less familiar with the term "paraphrasing" (Subekti, Yuhanna, et al., 2018). Moreover, it is vital to keep track of the detailed bibliographies of authors, titles, journal names, data, volume volumes, and pages (Elsevier, 2019). It will be more comfortable with the use of reference management applications (Ivey \& Crum, 2018; Speare, 2018) such as EndNote; Mendeley; RefWorks; Zotero (Ivey \& Crum, 2018), WizFolio, Docear, Qiqqa, ReadCube, Colwiz, and Paperpile (Speare, 2018). Similarly, analyzing information from books possesses $38.1 \%$ of mastery, which points out that some teachers do not often use textbooks or other offline sources. They seem more dependent on online sources of information.

By looking at the percentage of all the indicators, it concludes that most of the teachers gain ILS after training session by at least $50 \%$ of them, except for writing scientific articles and using the information on books. The restrictions of writing articles wish to describe in detail in the next section.

\subsection{Analysis of the constraints resulting from article writing}

The literacy-related global trend had become more popular when UNESCO launched literacy programs in many fields, namely (a) literacy for education, (b) media, information, technology literacy, and (c) literacy understanding and literacy for life (Ahmadi \& Yulianto, 2017; UNESCO, 2017b). Writing activity is one of the most basic academic capabilities to be studied for interested researchers and to be explored in the field of education (Graham, 2018). Competence in the form of scientific communication is necessary for success in such academic skills (Anderson, Lee, Byars, Baldwin, Cameron, \& Chang, 2016), which is one of the indicators of the existence of artifacts in the form of scientific writing.

Building a reading and writing culture is a challenge (UNESCO, 2017a). Susantini, Rahayu, Budiono, and Raharjo (2015) noted that in Indonesia around 2.6 million teachers who are under civil servant status, only $0.87 \%$ of teachers are categorized IV-b, $0.07 \%$ for IV-c, and $0.02 \%$ for IV-d in their academic career. Based on this data, writing is very critical to level up the competencies among teachers when they need to upgrade their professional status. 
NVivo query in Figure 6 below presents the barriers faced by participants in writing scientific articles. Based on the NVivo queries diagram, there are four problems from the largest to the smallest portion, namely, knowledge related to writing, time management, focus during writing, and motivation to write. As stated in the analysis of ILS, knowledge of writing is related to the way teachers use references and extract information. In training, some of the teachers were still trying to familiarize them with how to cite references and avoid plagiarism, whereas the others were still copying other people works.

In time management problem, the demand of teaching for 40 hours a week as the requirement to get the additional support of professional development still hold the teachers to start writing (Hidayati, Fatkhurahman, \& Suroto, 2017). Indeed, to fulfill the requirement, some teachers in Indonesia still have to put efforts searching for more teaching time (Meliana, Hasyim, \& Nurmalisa, 2018). Therefore, it finally impacts the teachers' motivation concentration while writing. Although it is not easy, the element of scientific writing must exist at each level for the teachers.

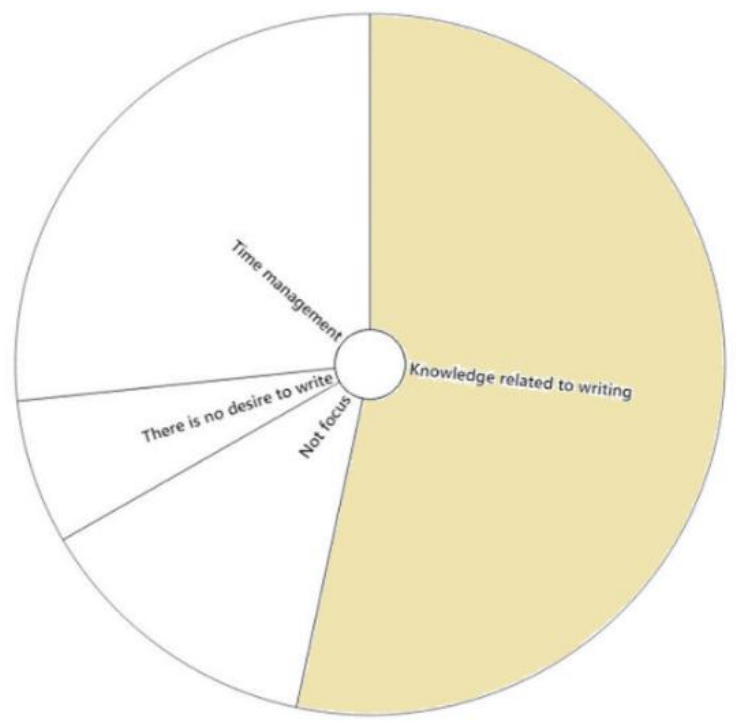

Figure 6. Problems faced by participants in writing scientific articles

\subsection{Results of training analysis are considered important}

Training programs can contribute to improving the level of research skills, learning processes, and achieving learning objectives, improving teacher performance and abilities (Al-qout, 2017). Next, the illustration of the results of the NVivo query in Figure 7 about the training activity required and perceived by participants for their professional development as educators.

Based on the outcomes of the NVivo inquiry, the data reveals that there are seven critical points concerning the desired training activity in developing competence as an educator. The dominant training activities mentioned are supporting instructional media, improving innovative learning, strengthening information technology skills, and doing productive writing. Meanwhile, the least dominant activities needed to emerge are doing journal publication, managing journal, and writing textbooks. 


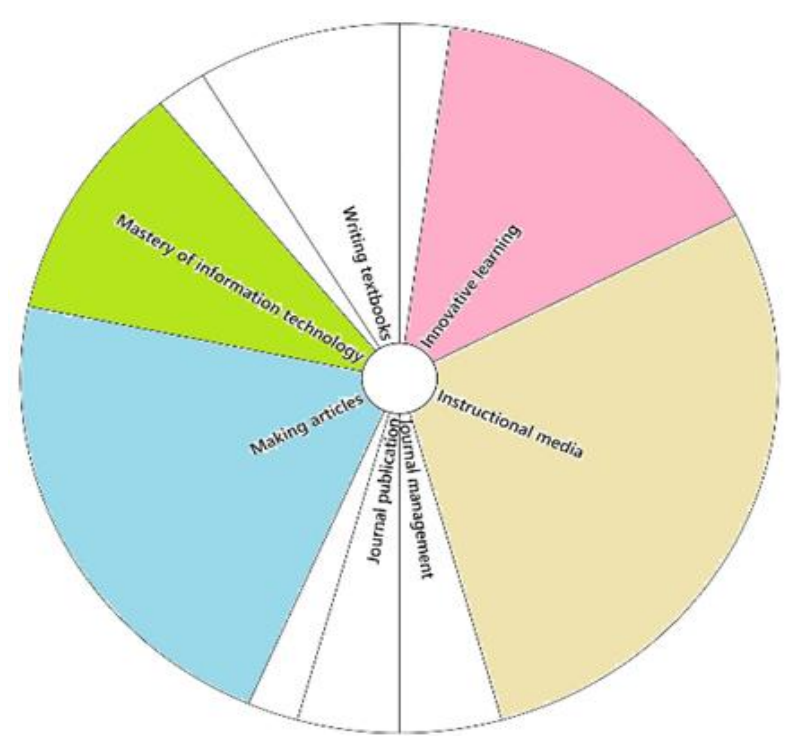

Figure 7. Visualization of the required and essential training activities

Following professional development, four large portions of activities in the figure above contribute directly to the teachers' ILS. Making articles and innovating learning, for instance, are interrelated to each other to support the teachers (Anastasiades \& Zaranis, 2017; Seel, Lehmann, Blumschein, \& Podolskiy, 2017) produce productive writing and ameliorate ILS as well. Likewise, both instructional media and information technology seem to have a direct link in the digital era, and therefore provide a better learning process (Suryanto, 2017). For the smallest portion activities, only writing textbook can inherently increase ILS. Those who have passions for managing journal in one institution need journal management and journal publications activities. In the daily activities, teachers need learning media as one of the tools used to influence the learning process in the classroom (Ntobuo, Arbie, \& Amali, 2018) and to encourage an effectual and streamlined learning process (Risnawati, Amir, \& Sari, 2018), and therefore, making complex concepts more accessible and more precise (Khoiriah, Jalmo, \& Abdurrahman, 2016; Ntobuo, Arbie, \& Amali, 2018).

Different to the data presented in Figure 7, Figure 8 represent what ultimate keywords for future educational training. The keywords function to direct what materials should be provided to the teachers if they want to increase ILS in terms of innovative learning, productive writing, information technology, and instructional media.

From the results of NVivo query as shown in Figure 8, it is known that there 10 keywords which appear in the analysis, namely, 1) making [pembuatan], 2) scientific [ilmiah], 3) innovative [inovatif ], 4) and [dan], 5) books [buku], 6) writing [menulis], 7) journal [jurnal], 8) teaching and learning [pembelajaran], 9) media [media], and 10) teacher-training [pelatihan]. Moreover, Figure 8 illustrates that teaching and learning, media, teacher-training, innovation, and writing scientific articles are no doubt important for the further training session to develop their profession as educators. Teaching and learning are still in the most considerable portion of the expected training material. The teachers need to get in line their 
ILS with their primary roles in schools. Also, teaching-learning and media become an interrelated source for mastering ILS. That is why the media have the second-largest portion in the analysis.

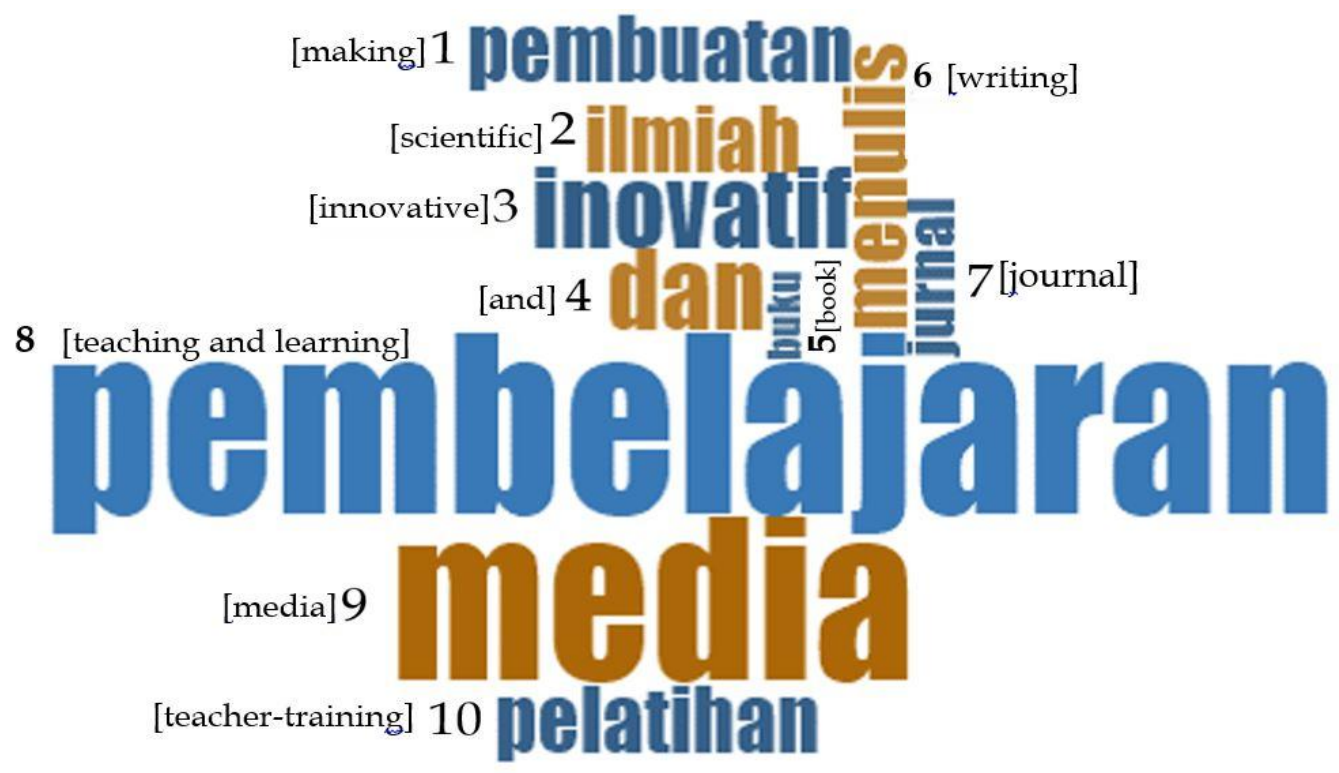

Figure 8. Visualization of NVivo questions: The constraints to writing scientific articles

Besides, the results of the NVivo query in Figure 9 helps visualize a second level theme with the keyword learning.

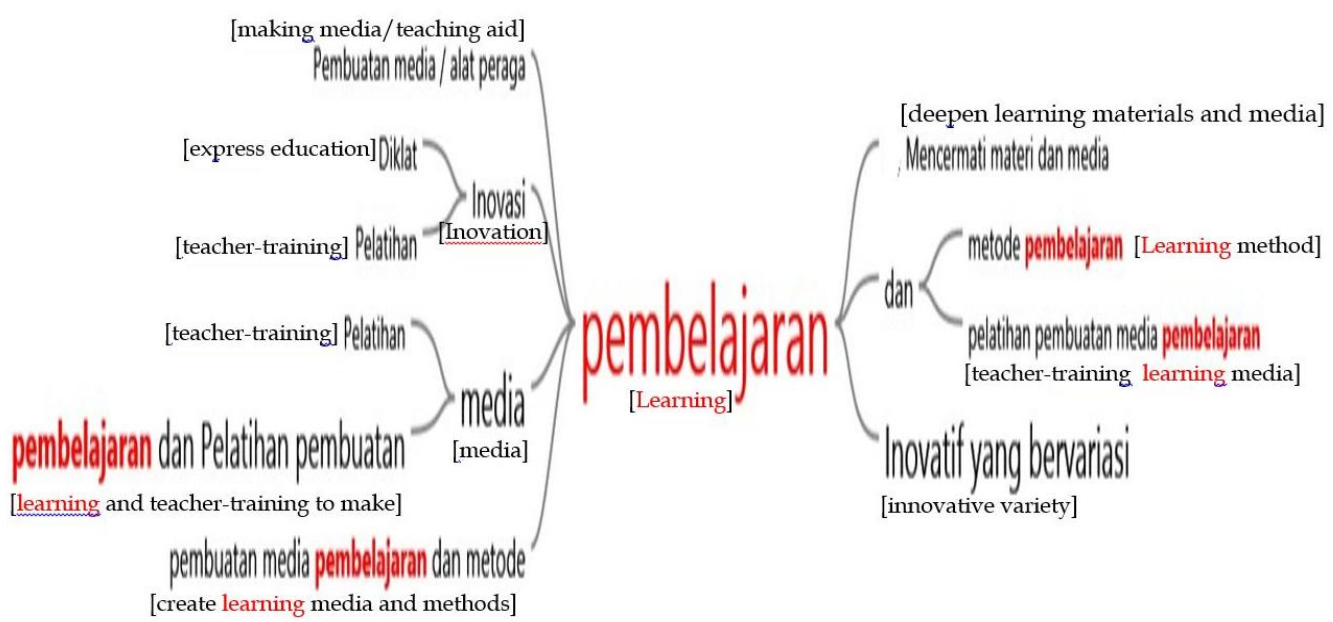

Figure 9. Visualization of the NVivo question published on two learning themes

According to Figure 9, it maps the second phase of the theme, which is considered substantial (learning). The "media and innovative learning" theme on both sides is critical elements about the training required for educators. This finding confirms that to plan quality education need a learning medium tailored to the improvement of children and the advancement of current technology. In line with this, UNESCO recommends blended learning to include topics, for instance, 'learning how to learn' and the perfection of information and communication technology literacy (UNESCO, 2016). According to UNESCO's 
recommendation, the use of digital media for students is to support researchbased teaching and learning activities.

Teacher training, considered as a group of related activities to achieve a capacity building, will equip teachers with the capacity to do their practice productively and efficiently. This paper provides sufficient support for the idea that the development of ILS and the writing of scientific articles is an essential constituent as part of the development and perfection of learning quality through the development of innovative media and learning.

\section{Conclusion}

It is reasonable to conclude that the teachers' ILS vary from one to the others with the highest percentage of two indicators, namely, determining types of information and understanding research terminologies. What the teachers need to do when they want to improve ILS, they have to deal with the issues related to scientific writing skills and accessing information from books. One of the reasons why the teachers' ILS cannot be categorized good because they must fulfill teaching time at least 40 hours a week as mandated in the policy. Thus, there has to be another teacher training to increase ILS. It can comprise activities primarily in the development of learning media, article making, learning innovation, and information-communication technology.

Although this research has done very well, it cannot handle all issues related to ILS. The two of them are: (a) the need for research related to strengthening ILS using written reference management and (b) the use of digital media for students to support teaching and learning activities research using the latest developments in information technology.

\section{Acknowledgments}

First of all, we would like to thank Universitas Negeri Malang and Universitas Negeri Surabaya for providing us with an opportunity to genuinely learn and access the vast amount of information to strengthen the method used in this research. Grateful acknowledgment to the Ministry of Research, Technology and Higher Education of the Republic of Indonesia (Kemristekdikti) for the privilege which enables us to prepare and carry out the process of the research. Finally, we have significantly benefitted from the Board of Education and Training Government (BPSDM) of East Java for the support of the administration and places for this research.

\section{References}

Ahmadi, A., \& Yulianto, B. (2017). Descriptive-analytical studies of literacy movement in Indonesia, 2003-2017. International Journal of Humanities and Cultural Studies, 4(3), 16-24.

Aisyah, E. N. \& Mahanani, P. (2017). Pelatihan menulisan artikel ilmiah bagi guru sekolah dasar dan taman kanak-kanak Kecamatan Tajinan Kabupaten Malang. [Practice writing scientific articles for low school teachers and tadika in Tajinan Malang District]. Abdimas Pedagogi, 1(1), 22-26. 
Alba, A. B., \& Trani, L. C. (2018). The extent of utilization of information and communication technology (ICT) by the selected secondary school division of Malolos: Base for the development of the strategic action plan. International Journal of Education and Research, 6(1), 181-188.

Alqahtani, R. A., Aldahash, M. A., Alhulail, S. A., Alzahrani, M. Y., Alfehaid, L., \& Almodaimegh, H. (2019). Experience of and attitudes toward research among pharmaceutical sciences and PharmD students in Saudi Arabia. Health Professions Education, 5(1), 58-65. doi:10.1016/j.hpe.2018.05.002

Al-qout, G. A. (2017). Historical research skills development in light of a training program for secondary stage history teachers. Journal of Education and Practice, 8(10), 38-53.

Anastasiades, P., \& Zaranis, N. (2017). Research on e-learning and ICT in education_ technological, pedagogical, and instructional perspectives. Switzerland: Springer International Publishing.

Anderson, C. B., Lee, H. Y., Byars W., A., Baldwin, C. D., Cameron, C., \& Chang, S. (2016). Assessment of scientific communication self-efficacy, interest, and outcome expectations for career development in academic medicine. Journal of Career Assessment, 24(1), 182-196. doi:10.1177/1069072714565780

Bailey, A. L., Maher, C. A., \& Wilkinson, L. C. (2018). Language, literacy, and learning in the STEM disciplines: how language counts for English learners. New York: Routledge.

Bordens, K. S., \& Abbott, B. B. (2018). Research design and methods: A process approach. New York: McGraw-Hill.

Budd, J. M., \& Suorsa, A. (2019). A phenomenological imperative for information literacy. Paper presented at the European conference on information literacy, Oulu, Finland.

Chiarella, D., Khadem, T. M., Brown, J. E., \& Wrobel, M. J. (2014). Information literacy skills retention over the first professional year of pharmacy school. Medical Reference Services Quarterly, 33(3), 302-312. doi:10.1080/02763869.2014.925693

$\mathrm{Chu}, \mathrm{H} .$, \& Ke, Q. (2017). Research methods: What is in the name? Library \& Information Science Research, 39(4), 284-294. doi:10.1016/j.lisr.2017.11.001

Cicek, S. A., Cankaya, I., Ucer, H., \& Cetin, M. (2017). The effect of information literacy on teachers' critical thinking disposition. Journal of Education and Learning, 6(3), 31-40. doi:10.5539/jel.v6n3p31

Çoklar, A. N., Yaman, N. D., \& Yurdakul, I. K. (2017). Information literacy and digital nativity as determinants of online information search strategies. Computers in Human Behavior, 70, 1-9. doi:10.1016/j.chb.2016.12.050

Corrall, S. (2017). Crossing the threshold: reflective practice in information literacy development. Journal of Information Literacy, 11(1), 23-53. doi:10.11645/11.1.2241

De Meulemeester A., De Maeseneer J., De Maeyer S., Peleman R., \& Buysse H. (2019). Information literacy self-efficacy of medical students: a longitudinal study. Communications in Computer and Information Science, 989, 264-272. doi:10.1007/978-3-030-13472-3_25

Edmonds, W. A., \& Kennedy, T. D. (2017). An applied guide to research designs: quantitative, qualitative, and mixed methods. London: SAGE Publications, Inc.

Elsevier. (2019). Information and management: the international journal of information systems theories and applications. Retrieved from http://bit.ly/2YaLZq3

Feng, L., \& Ha, J.L., (2016). Effects of teachers' information literacy on lifelong learning and school effectiveness. Eurasia Journal of Mathematics, Science \& Technology Education, 12(6), 1653-1663. doi: 10.12973/eurasia.2016.1575a 
Flierl, M., Bonem, E., Maybee, C., \& Fundator, R. (2018). Information literacy supporting student motivation and performance: Course-level analyses. Library $\mathcal{E}$ Information Science Research, 40(1), 30-37. doi:10.1016/j.lisr.2018.03.001

Goldsmith, R., Willey, K., \& Boud, D. (2017). Investigating invisible writing practices in the engineering curriculum using practice architectures. European Journal of Engineering Education, 44(1-2), 71-84. doi:10.1080/03043797.2017.1405241

Graham, S. (2018). Introduction to conceptualizing writing. Educational Psychologist, 53(4), 217-219. doi:10.1080/00461520.2018.1514303

Hai-Jew, S. (2015). Enhancing qualitative and mixed methods research with technology. Hershey: IGI Global.

Hidayati, Fatkhurahman, \& Suroto, B. (2017). Pelatihan manajemen penulisan karya tulis ilmiah bagi tenaga pendidik di SMPN 3 Kampar Kiri Tengah. [Arranging management of scientific papers for teaching staff at Kampar 3 Middle School Middle School]. Dinamisia, 1(1), 122-128. doi:10.31849/dinamisia.v1i1.425

Ibrahim, G. A., Ismadi, H. D., Zabadi, F., Ali, N. B. V., Alipi, M., Antoro, B., Hanifah, N., Miftahussururi, Nento, M. N., Akbari, Q. S., \& Aziz, M. (2017). Peta jalan gerakan literasi nasional. [Road map of the national literacy movement]. Jakarta.

Ivanova, S. V., Frolov, A., \& Nikulchev, E. V. (2016). Challenges and prospects of using information technologies in higher education. SHS Web of Conferences, 29, 1-4. doi: 10.1051/shsconf/20162902015

Ivey, C., \& Crum, J. (2018). Choosing the right citation management tool: Endnote, Mendeley, RefWorks, or Zotero. Journal of the Medical Library Association, 106(3), 399-403. doi:10.5195/jmla.2018.468

Kavšek, T., Peklaj, C., \& Žugelj, U. (2016). Information literacy training evaluation: The case of first-year psychology students. The Journal of Academic Librarianship, 42(4), 293-299. doi:10.1016/j.acalib.2016.06.008

Kemendikbud. (2016a). Pedoman kegiatan pengembangan keprofesian berkelanjutan bagi guru pembelajar. [Guideline for ongoing professional development activities for learning teachers]. Jakarta: Directorate General of Teachers and Education, Ministry of Education and Culture of the Republic of Indonesia.

Kemendikbud. (2016b). Penilaian kegiatan pengembangan keprofesian berkelanjutan guna mendukung pengembangan profesi guru pembelajar (PPGP). [Assess ongoing professional development activities to support the development of teaching professional learning (PPGP). Jakarta: Directorate General of Teacher and Education, Ministry of Education and Culture of the Republic of Indonesia.

Khan, A., Idrees, H., Asghar, A., \& Aziz, U. (2016). Information literacy for visually impaired teachers in Pakistan. Journal of Librarianship and Information Science, 50(1), 14-22. doi:10.1177/0961000616662700

Khoiriah, Jalmo, T., \& Abdurrahman. (2016). The effect of multimedia-based teaching materials in science toward students' cognitive improvement. Indonesian Journal of Science Education, 5(1), 75-82. doi:10.15294/jpii.v5i1.5793

Kim, S.Y., Graham, S. S., Ahn, S., Olson, M. K., Card, D. J., Kessler, M. M., DeVasto, D. M., Roberts, L. R., \& Bubacy, F. A. (2016). Correcting biased cohen's kappa in NVivo. Communication Methods and Measures, 10(4), 217-232. doi:10.1080/19312458.2016.1227772

Koltay, T., Špiranec, S., \& Karvalics, L. Z. (2016). Research 2.0 and the future of information literacy. Cambridge: Chandos Publishing.

Krahe, M., Milligan, E., \& Reilly, S. (2019). Personal health information in research: Perceived risk, trustworthiness, and opinions from patients attending a tertiary healthcare facility. Journal of Biomedical Informatics, 95, 1-10. doi:10.1016/j.jbi.2019.103222 
Leavy, P. (2017). Research design: quantitative, qualitative, mixed methods, arts-based, and community-based participatory research approaches. London: The Guilford Press.

Liou, S. R., Yu, W. C., Tsai, H. M., \& Cheng, C. Y. (2015). Teaching information literacy in nursing using blended learning pedagogy. Creative Education, 6(13), 1446-1455. doi:10.4236/ce.2015.613145

Lune, H., \& Berg, B. L. (2017). Qualitative research methods for the social sciences. London: Pearson Education.

Maher, C., Hadfield, M., Hutchings, M., \& Eyto, A. D. 2018. Ensuring rigor in qualitative data analysis: a design research approach to coding combining NVivo with traditional material methods. International Journal of Qualitative Methods, 17(1), 113. doi: $10.1177 / 1609406918786362$

McDougall, J., Readman, M., \& Wilkinson, P. (2018). The uses of (digital) literacy. Learning, Media, and Technology, 43(3), 263-279. doi:10.1080/17439884.2018.1462206

McGuinnes, C., \& Fulton, C. (2019). Digital literacy in higher education: a case study of student engagement with e-tutorial using blended learning. Journal of Information Technology Education: Innovations in Practice, 18, 1-28. doi:10.28945/4190

Meliana, D. E., Hasyim, A., \&Nurmalisa, Y. (2018). Pengaruh sertifikasi guru terhadap kompetensi pedagogik dalam mengajar di SMAN 1 Bangunrejo. [The impression of the teacher's resilience towards the efficiency of pedagogy in teaching at SMAN 1 Bangunrejo]. Jurnal Kultur Demokrasi, 5(9), 7-32.

Montrieux, H., Vanderlinde, R., Schellens, T., \& De Marez, L. (2015). Teaching and Learning with Mobile Technology: A Qualitative Explorative Study of the Introduction of Tablet Devices in Secondary Education. PLoS One, 10(12), 1-17. doi:10.1371/journal.pone.0144008

Ntobuo, N. E., Arbie, A., \& Amali, L. N. (2018). The development of gravity comic learning media based on Gorontalo culture. Indonesian Journal of Science Education, 7(2), 246-251. doi:10.15294/jpii.v7i2.14344

Nwosu, O. C., Obiamalu, A. R., \& Udem, O. K. (2015). Relationship between Information Literacy Skills and Research Output of Academic Staff in Nnamdi Azikiwe University Awka, Nigeria. Journal of Applied Information Science and Technology, 8(1), 89-108.

Risnawati, Amir, Z., \& Sari, N. (2018). The development of learning media based on visual, auditory, and kinesthetic (VAK) approach to facilitate students' mathematical understanding ability. Journal of Physics: Conference Series, 1028, (012129), 1-7. doi:10.1088/1742-6596/1028/1/012129

Samani, M. (2017). The role of education in cultivating the character of professional leaders in the 21st century. Surabaya: Indonesian Navy Academy.

Sardon, A. N., \& Tignor, M. (2018). Focus on the facts: A news and information literacy instructional program. The Reference Librarian, 59(3), 108-121. doi:10.1080/02763877.2018.1468849

Saunders, L. (2018). Information literacy in practice: Content and delivery of library instruction tutorials. The Journal of Academic Librarianship, 44(2), 269-278. doi:10.1016/j.acalib.2017.12.022

Seel, N. M., Lehmann, T., Blumschein, P., \& Podolskiy, O. A. (2017). Instructional design for learning theoretical foundations. Rotterdam: Sense Publishers.

Shao, X., \& Purpur, G. (2016). Effects of information literacy skills on student writing and course performance. The Journal of Academic Librarianship, 42(6), 670-678. doi:10.1016/j.acalib.2016.08.006 
Shorsher, A. Y., \& Bronstein, J. (2018). Three Perspectives on Information Literacy in Academia: Talking to Librarians, Faculty, and Students. College \& Research Libraries, 79(4), 535-553. doi:10.5860/crl.79.4.535

Shreffler, S., \& Gauder, H. (2018). Exercising research skills: An information literacy boot camp for religious studies, graduate assistants. Journal of Religious \& Theological Information, 17(1) 134-144. doi:10.1080/10477845.2018.1467821

Slavin, R. (2018). Educational Psychology (3edition). New York: Pearson.

Speare, M. (2018). Graduate student use and non-use of reference and pdf management software: an exploratory study. The Journal of Academic Librarianship, 44(6), 762774. doi:10.1016/j.acalib.2018.09.019

Subekti, H., Purnomo, A. R., Susilo, H., Ibrohim, I., \& Suwono, H. (2018a). Analysis of preservice science teacher information literacy towards research skills. Journal of Physics: Conference Series, 1006(012009), 1-6. doi:10.1088/17426596/1006/1/012009

Subekti, H., Purnomo, A. R., Susilo, H., Ibrohim, \& Suwono, H. (2018b). Comparison of student achievement in agricultural biotechnology-stem integrated using research-based learning. Journal of Physics: Conf. Series, 1108(012100), 1-6. doi:10.1088/1742-6596/1108/1/012100

Subekti, H., Yuhanna, W. L., Susilo, H., Ibrohim, \& Suwono, H. (2018). Representation of mutual terms and research skills towards grade point average: Exploration study. Florea, 5(1), 1-10. doi:10.25273/florea.v5i1.2500

Suryanto, H. (2017). Penerapan media pencils dalam meningkatkan pemahaman siswa pada materi rangkaian hambatan listrik. [Application of media pencils in improving students' understanding of electric resistance circuits]. SEJ (Science Education Journal), 1(1), 1-6. doi:10.21070/sej.v1i1.833

Susantini, E., Rahayu, Y. S., Budiono, D., \& Raharjo. (2015). Profil artikel ilmiah buatan guru pada pelatihan penulisan karya ilmiah bagi guru-guru di smp lab school Surabaya[The profile of scientific articles was made by the teacher in training to write scientific papers for teachers in the Surabaya secondary school laboratory] Jurnal ABDI, 1(1), 1-7.

Swaramarinda, D. R. (2018). The usefulness of information and communication technology in entrepreneurship subject. Journal of Entrepreneurship Education, 21(3), 1-10.

Ukachi, N. B. (2015). Exploration of information literacy skills status and impacts on the quality of life of artisans in Lagos, Nigeria. New Library World, 116(10), 578-587. doi:10.1108/nlw-01-2015-0006

UNESCO. (2016). Blended learning for quality higher education: Selected case studies on implementation from Asia-Pacific. Bangkok: UNESCO Bangkok Office.

UNESCO. (2017a). Fostering a culture of reading and writing: Examples of dynamic literate environments. Hamburg: UNESCO Institute for Lifelong Learning.

UNESCO. (2017b). Reading the past, writing the future: fifty years of promoting literacy. Paris: United Nations Educational, Scientific, and Cultural Organization.

Walker, M. A. \& Li, Y. (2016). Improving information literacy skills through learning to use and edit Wikipedia: A chemistry perspective. Journal of Chemical Education, 93(3), 509-515. doi:10.1021/acs.jchemed.5b00525

Woolf, N. H., \& Silver, C. (2018). Qualitative analysis using NVivo: The five-levell QDA method. New York: Routledge.

Zane, M., \& Tucci, V. K. (2015). Exploring the information literacy needs and values of high school chemistry teachers. Journal of Chemical Education, 93(3), 406-412. doi:10.1021/acs.jchemed.5b00450 